\title{
Sosialisasi Social Distancing Bagi Generasi Milenial Di Desa Padak Guar Kecamatan Sambalia Kabupaten Lombok Timur
}

\author{
${ }^{1}$ Lalu Hendra Maniza, ${ }^{2}$ Sulhan Hadi, ${ }^{3}$ Abdul Hafiz \\ ${ }^{1,2}$ Prodi Administrasi Bisnis, Universitas Muhammadiyah Mataram \\ ${ }^{3}$ Prodi D3 Perpustakaan, Universitas Muhammadiyah Mataram \\ Email Korespondensi: Manizahendra@gmail.com
}

\begin{abstract}
This community service report is entitled "Social Distancing Socialization for Millennial Generation in Padak Guar Village, Sambalia District, East Lombok Regency". The goal of this commonity service is, first, to raise awareness about the importance of social distancing and physical distancing; secondly, to provide knowledge for people in Padak Guar Village, East Lombok Regency about Covid 19, ways of transmission, symptoms and treatment and thirdly, to provide knowledge about how to carry out daily life activities so that people can meet their daily needs so that their economies remain walk normally. The method applied is face to face and discussion. The results obtained from this Community Service are increasing knowledge for the participants, in this case the people in Padak Guar Village, about the awareness of the importance of social distancing and physical discourse to agains the spread of the corona virus.
\end{abstract}

Keywords: Social Distancing, Corona Virus, Labulia Village

Abstrak. Pengabdian Kepada Masyarakat ini berjudul "Sosialisasi Social Distancing Bagi Generasi Milenial Di Desa Padak Guar Kecamatan Sambalia Kabupaten Lombok Timur”. Pengabdian ini dilakukan dengan beberapa tujuan, pertama, untuk meningkatkan kesadaran tentang pentingnya melakukan sosial distancing dan phyisical distancing; kedua, untuk memberikan pengetahuan bagi masyarakat di Desa Padak Guar Kabupaten Lombok Timur tentang Covid 19, cara penularan, gejala dan penanganannya dan ketiga, untuk memberikan pengetahuan tentang cara melakukan aktivitas-aktivitas kehidupan sehari-harinya agar masyarakat dapat memenuhi kebutuhan hidupnya sehingga perekonomian mereka tetap berjalan normal. Metode yang diterapkan adalah tatap muka dan diskusi. Hasil yang diperoleh dari Pengabdian Kepada Masyarakat ini adalah bertambahnya pengetahuan bagi para peserta yang dalam hal ini adalah masyarakat di Desa Padak Guar tentang kesadaran pentingnya melakukan sosial distancing dan pisikal discancing dalam memerangin penyebaran virus corona.

Kata kunci: Sosial Distancing, Virus Corona, Desa Labulia

\section{PENDAHULUAN}

Di era pandemic corona saat ini, siapa yang masih asing dengan istilah social distancing ? Social distancing menjadi terminologi yang sangat popular hampir di seluruh kalangan masyarakat Indonesia. Bahkan di negara-negara yang menjadi area penyebaran dari virus Covid 19, social distance menjadi salah satu kebijakan yang diterapkan untuk mengurangi jumlah warga yang dapat terpapar Covid 19.

Dalam ilmu komunukasi Pada Dasarnyaa Social dictance mengacu pada bagiamana tingkat penerimaan orang terhadap orang lain di luar kelompok atau kelas sosial mereka sendiri. Tingkat penerimaan ini ditentukan oleh perasaan umum mereka terhadap orang lain, dan jumlah interaksi sosial yang mereka miliki dengan orang-orang yang karakteristiknya berada di luar norma sosial mereka. Jarak sosial adalah ukuran perbedaan yang dirasakan (atau jarak) antara kelompok (Airth,Maria).

Jarak sosial (social distance) dapat didefinisikan berdasarkan zona prosemik yang digunakan antar individu ketika berinteraksi dengan individu lainnya. Menurut Edward T. Hall, terdapat empat zona proksemik, yaitu 
zona intim, zona pribadi, zona sosial, dan zona publik.

1. Zona intim $(0-18$ inci $)$ - zona intim adalah jarak dekat biasanya dilakukan oleh keluarga inti, teman dekat, kekasih, dan pasangan hidup.

2. Zona pribadi (18 inci - 4 kaki) disediakan untuk percakapan dengan teman, keluarga besar, rekan kerja, dan diskusi kelompok.

3. Zona sosial $(4-10$ kaki $)-$ diperuntukkan bagi kelompok yang baru terbentuk atau orang-orang baru.

4. Zona publik (10 kaki - atau lebih) diperuntukkan bagi khalayak luas, orang asing, dan lain-lain.

Terkait jarak sosial (social distance), Burgoon menyatakan bahwa manusia memiliki kebutuhan akan afiliasi dan ruang pribadi. Dalam artian bahwa manusia selalu ingin dekat secara fisik dengan manusia lainnya terutama orang yang memiliki kedekatan personal dengan kita. Namun disaat bersamaan kita sebagai individu juga tetap harus menjaga jarak dengan orang lain yang kita anggap asing, sebagai bentuk perlindungan diri dari ancaman yang mungkin dari orang yang kita anggap asing tersebut.

Seperti yang kita ketahui bersama bahwa dunia saat ini sedang dilanda pandemi virus yakni Corona Virus Disease 2019 (Covid19) yang tingkat penyebarannya begitu cepat dan sangat mengawatirkan, sehingga semua negara mencari cara yang paling tepat untuk memperlambat bahkan untuk menghentikan penyebaran virus ini. Ada tiga solusi yang bisa digunakan untuk memperlambat dan mengentikan penularan virus covid19:

1. Menemukan vaksin covid19 secepat mungkin

2. Lockdown (penutupan wilayah secara total)

3. Social distancing/physical distancing (pembatasan interaksi Social secara langsung)

Untuk solusi yang pertama saat ini belum bisa dilaksanakan karena meemukan vaksin untuk mengobati virus diperlukan waktu minmal satu tahun, karena harus melewati percobaanpercobaan dan uji laboratorium. Untuk solusi yang kedua, tidak semua negara bisa melaksanakan karena terkait dengan masalah ekonomi, ahirnya banyak negara yang menggunakan solusi yang ketiga yakni Social distancing (pembatasan interkasi social secara fisik )

Di Indonesia masyarakat yang terpapar virus ini semakin meningkat dalam beberapa waktu belakangan ini, sehingga hal tersebut dijadikan masalah nasional oleh pemerintah indonesia. Korban terimfeksi Virus Corona tidak saja berada di daerah perkotaan, wilayah pedesaan juga banyak masyarakatnya yang tidak luput menjadi korban terinfeksi Virus Corana ini. Penyebaran virus ini sangat cepat apabila ada seorang yang terinfeksi virus ini dia akan gampang mengimfeksi orang lain yang diajak kontak langsung tanpa melihat usia dan jenis kelamin.

Di Indonesia, status pembatasan social diumumkan oleh presiden sekitar bulan maret 2020. Karena langkah ini dianggap mampu menghambat penyebaran virus corona di kalangan masyarakat, dikarenakan penyakit yang diakibatkan oleh virus corona ini belum di temukan vaksin pengobatan untuk menyembuhkan orang yang terinfeksi sehingga satu-satu usaha yang bisa dilakukan saat ini adalah lebih baik mencegah dari pada mengobati.

Usaha pencegahan yang bisa dilakukan oleh masyarakat seperti membiasakan pola hidup sehat,dengan cara mebersihkan lingkungan tempat tinggal dengan cara menyemprot menggunakan disinkfentan, mencuci tangan sesering mungkin dengan sabun, menggunakan masker dan yang tidak kalah pentingnya mejaga kekebalan Imun tubuh kita dengan mengkonsumsi makanan yang sehat, istirahat yang cukup dan berolahraga, kalau tubuh sudah sehat nanti ketika ada virus yang masuk ketubuh kita imun kekebalan tubuh ini yang akan berperang melawan virus corona ini.

Virus corona ini membutuhkan 14 hari (masa inkubasi) di didalam orang yang terimfeksi dengan menimbulkan gelaja seperti flu, suhu tubuh diatas $37^{\circ} \mathrm{C}$, batuk, sesak nafas, jika masa inkubasi virus ini bisa 
dilewati oleh sesorang yang terimfeksi, maka orang ini akan bisa sembuh dan akan memiliki imun yang bagus terhadap virus corana ini.

Nusa Tenggara Barat adalah daerah yang Salah satu termasuk daerah zona merah penyebaran virus corana ini, kasus pertama yang ditemukan di NTB adalah warga yang berasal dari Kabupaten Lombok Timur, Kecamatan Aikmel. Berdasarkan informasi dari kepala Desa Padak Guar TARMIZI. Desa Padak Guar ini masuk dalam zona merah penyebaran virus Corona mengingat desa Padak Guar ini merupakan daerah Pariwisata dan tempat berdirinya proyek pembangkit tenaga listrik (LED) diamana banyak karyawan yang bekerja di proyek tersebut berasal dari luar daerah Nusa Tenggara Barat seperti Pulau Jawa, Jakrta dan bahkan ada dari Negara Cina . Zona merah ini maksudnya adalah zona rawan, sebab disana banyak terjadi orang keluar masuk. Oleh karena itu diperlukan adanya sosialisasi dalam pembatasan sosial, bagi masyarakat yang berada desa Padak Guar khususnya kalangan generasi milenial yang masih sering nekat kumpul-kumpul bankan keluyuran keluar rumah tanpa alas an yang jelas.

Hal tersebut jelas menjadi permasalahan bagimasyarakat di Desa Padak Guar, karena dampak dari penyebaran virus corona ini sangat meresahkan masyarakat, ditambah dengan kasus orang yang terimpeksi di Nusa Tenggara Barat terus meningkat hari demi hari.

\section{METODE PELAKSANAAN}

Berdasarkan permasalahan yang dihadapi oleh mitra, beberapa alternatif solusi yang dapat ditawarkan adalah sebagai berikut, yaitu :

1. Memberikan penyuluhan kepada masyarakat bagaimana cara mencegah penularan Convid 19 (Virus Corona) di Desa Padak Guar.

2. Memberikan penyuluhan kepada masyarakat, dampak bahaya yang ditimbulkan oleh Virus Corona bagi Masyarakat di Desa Padak Guar.

\section{HASIL DAN PEMBAHASAN}

Pelaksanaan kegiatan sosialisasi sosial distancing bagi generasi melenial di Desa Padak Guar Kecamatan Sambalia Kabupaten Lombok Timur, berjalan dengan lancar. Hal ini terlihat dari antusiasme dan jumlah peserta yang diundang melebihi jumlah yang diundang dan peserta sanagat semangat memperhatiakn materi yang diberikan oleh pemateri kalau ada yang belum jelas peserta merespon materi pelatihan yang diberikan oleh tim pengabdian dengan cara mengajukan pertanyaan. Pada saat memberikan materi, pemateri tidak mengalami kendala dikarenakan tempat yang digunakan untuk sosialisasi sangat mendukung dan dari peserta juga memiliki pengetahuan yang bagus juga dalam menerima materi yang dipaparkan pemateri. Keberhasilan pelaksanaan kegiatan ini tidak lepas dari dukungan Ketua Pemuda Desa Padak Guar yang sangat bersemangat mengumpulkan peserta pelatihan.

Hasil dari kegiatan sosialisasi ini adalah para pemuda yang berada di Desa Padak Guar memperoleh pengetahuan tentang:

1. Makna dari sosial distancing dan pisikal distancing, cara melakukan sosial distancing, cara melakukan pisikal distancing.

2. Mampu melakuakan tindakan atau memberi contoh kepada masyarakat lain cara melakukan sosial distaning dan pisikal distancing

3. Mengetahui apa itu Covid 19, Cara penularan, gejala dan tindakan pencegahan

4. Peserta mampu dengan mandiri melakukan pencegahan dari penyebaran virus covid 19

5. Peserta mampu menjadi protokol pencegahan covid 19 di desa Padak Guar

\section{KESIMPULAN}

Melalui kegiatan sosialisasi ini diharapkan dapat memberikan pemahaman kepada para generasi melenial di desa Padak Guar tentang cara melakukan pencegahan penyebaran dari covid 19 atau corona, sehingga masyarakat yang berada dikawasan Desa Padak Guar bisa melakukan pencegahan dan mengetahui cara penyebaran dan penangannan jika ada anggota masyarakat yang diindikasi tertular dengan virus corona ini. Disamping itu para generasi melenial yang berada di desa Padak Guar diharapkan mampu menjadi garda terdepan dalam mengawasi para pengunjung wisatawan yang berasl dari luar desa Padak Guar 
dan para tenaga kerja perusahaan PT. LET dan PLN yang banyak di datangkan dai luar daerah atau Negara Cina.

\section{SARAN}

Mengingat peserta sosialisasi ini hanya diundang dari unsur pemuda hendaknya piahak Pemdes dan segenap aparatur untuk mendukung semua kegiatan yang diadakan oleh pemuda desa Padak Guar karena tanpa ada dukungan dari Pemerintah Desa , tentunya pemuda akan mengalami kendala untuk dapat mengaplikasikan apa yang sudah didapatkan dari program sosialisasi yang berlangsung cukup singkat. Karena itu kegiatan sosialisasi ini tidak cukup untuk mencapai tujuan kalau tidak ada tindak lanjut dari semua pemangku kebijakan yang ada di Desa Padak Guar ini, maka kegiatan ini perlu dilanjutkan oleh kegiatan lain yang lebih aplikatif di lapangan seperti:

1. Pembentukan team pecegahan penyebaran virus corona di kalangan melenial/pemuda, memberikan perlengkapan pecegahan seperti ember tepat cuci tangan yang dilengkapi dengan sabun yang ditaruh di pintu-pintu masuk dusun mauapun dikawasan pariwisata Gili Lampu.

2. Melibatkan para pemuda dan petugas kesehatan setempat dalam kegiatan pengecekan suhu tubuh dan karantina bagi orang luar yang masuk ke kawasan Desa Padak Guar

3. Perlu dilakukan setidaknya pembinaan yang lebih komprehensif bagi para generasi melenial/pemuda desa Padak Guar dalam pencehan penyebaran virus corona, sehinga anggota kelompok pemuda atau masyarakat terkait dapat memutus secara mandiri penyebaran virus corona sehingga masyarakat bisa melakukan kehidupan secara normal ditengah wabah virus corona ini mengingat sebagian besar masyarakat yang tinggal di Desa Padak Guar bermata pencaharian sebagai pedangang pesisir pantai, pemandu wisata dan nelayan.

Selain itu diperlukan kerja sama penyuluh dari Jurusan Ilmu Administrasi Bisnis Fakultas Ilmu Sosial dan Ilmu Politik Universitas Muhammadiyah Mataram dengan pihak lainnya dalam melakukan pengabdian masyarakat misal dengan pihak Pemerintah Kabupaten Lombok
Timur terutama pihak puskesmas dan BPB kecamatan Sambalia.

\section{UCAPAN TERIMA KASIH}

Kami selaku tim pengabdian mengucapkan terimakasih ke Lembaga Pengabdian Pada Masyarakat (LPPM) Universitas Muhammadiyah Mataram yang telah mendanai kegiatan pengabdian ini melalui hibah pengabdian Universitas Muhammadiyah Mataram. Sehingga kegiatan kami terlaksana dengan baik.

\section{DAFTAR PUSTAKA}

Airth,Maria

(https://study.com/academy/lesson/so

cial-distance-definition-

theory.html\#transcriptHeader)

Ausrianti, R., Andayani, R. P., Surya, D. O., \& Suryani, U. (2020). Edukasi Pencegahan Penularan Covid 19 serta Dukungan Kesehatan Jiwa dan Psikososial pada Pengemudi Ojek Online. Jurnal Peduli Masyarakat, 2(2), 59-64.

Hall, Edward T. (1966). The Hidden Dimension. Doubleday and Company, Inc. New York.

Peraturan Gubernur Nusa Tenggara Barat Nomor 22 Tahun 2020 Tentang Pedoman Umum Penanganan Covid 19 Pemerintah Provinsi Nusa Tenggara Barat

West, Ricard; Lynn.H.Turner. (2013). Pengantar Teori Komunikasi; Analisis dan Aplikasi (3rd). Salemba Humanika: Jakarta

WHO. (2020). Anjuran mengenai penggunaan masker dalam konteks covid-19 ancaman krisis ekonomi global dari dampak penyebaran virus corona (covid-19)

World Health Organization. Novel Coronavirus (2019-nCoV) Situation Report-54 [Internet]. WHO; 2020 [updated 2020 March 15; cited 2020 March 30]. Available from: https://www.who.int/docs/defaultsource/coronaviruse/situationreports/20200314-sitrep-54-covid19.pdf?sfvrsn=dcd46351_2. 2020). 